\section{Success in Science Reflections of a Retired Scientist}

Hilton $\mathrm{H}$. Mollenhauer

The recent note by J.D. Watson in Science (1993) is another of the periodical advice columns in which someone of renown gives his or her perspective of how to succeed in this most difficult of fields. And a very good article it is. I find no fault with any of the four rules presented which I quote as follows: 1) "To succeed in science you have to avoid dumb people." 2) "To make a huge success, a scientist has to be prepared to get into deep trouble." 3) "Be sure you always have someone up your sleeve who will save you when you find yourself in deep s-." 4) "Never do anything that bores you." Unfortunately, these four rules are directed to a level of scientist that clearly bypasses most of us irrespective of how many good intentions we may have. Therefore I feel obliged to submit a revised list of thoughts for us average beings who plow through the days in an average research environment.

What follows is a list of statements by the author that reflect or relate to) the thoughts of many workers in the field of science. These statements are based on some 40 years in the research field at three well-respected research establishments. Clearly, there are many more statements here than the mere four of Professor Watson, perhaps reflecting the more mundane thinking processes of the average worker/scientist. Moreover, the things that trouble us are often quite obscure from the pure science that we are paid to pursue. These statements also reflect the fact that the vast majority of scientists are not free to pursue their most favored interests, and do not have the will or capability to escape their bonds. Nonetheless, it is possible even here to maximize productivity and, perhaps, ease some of the mental burdens that commonly prevail at this level.

\section{Basic}

To be a brilliant and creative scientist, YOU MUST BE BRILLIANT AND CREATIVE.

Fortunately, YOU DO NOT HAVE TO BE BRILLIANT AND CREATIVE TO LIVE A USEFUL AND PRODUCTIVE LIFE.

Above all else YOU MUST WANT TO SUCCEED, AND YOU MUST BE WILLING TO DO VERY NEARLY ANYTHING TO DO SO.

THE WORLD DOES NOT OWE YOU ANYTHING.

LIFE IS NOT NECESSARILY FAIR. If you expect it to be so, then you will be sorely disappointed, disillusioned, and will, ultimately, become bitter.

\section{Recognition}

ACCEPTANCE OUTSIDE YOUR IMMEDIATE ENVIRONS IS WHAT COUNTS (NEXT TO MONEY, THAT IS). If everyone out there likes you and/or your work, your boss is also likely to like you and/or your work.

Recognition for worthwhile achievements is usually slowly acquired THROUGH COMMUNICATION WITH ANYONE WHO WILL LISTEN AND WHO IS OUTSIDE YOUR IMMEDIATE ENVIRONS.

To achieve recognition, YOU HAVE TO OFFER SOMETHING THAT OTHER PEOPLE WANT OR NEED.

PUBLISH, ATTEND AND PARTICIPATE IN MEETINGS, TALK TO ANYONE WHO WILL LISTEN, CREATE CONTROVERSY.

IT USUALLY TAKES 5-10 YEARS (OR LONGER) TO BECOME A RECOGNIZED AUTHORITY ON ANY SUBJECT; therefore it behooves you to limit, and carefully define, your research interests.

\section{Work Habits}

WORK WITH, OR AT LEAST COMMUNICATE WITH, SOMEONE OUTSIDE YOUR LABORATORY - preferably someone who doesn't always agree with you.

TWO GOOD PEOPLE WORKING TOGETHER CAN EASILY TURN OUT FOUR TIMES THE PAPERS THAT COULD BE DONE WITHOUT SUCH COOPERATION.
YOU MUST BE AWARE OF WHAT OTHERS ARE DOING TO PUT YOUR OWN WORK INTO PROPER PERSPECTIVE.

As Watson (1993) points out, always ASSOCIATE, AND WORK WITH, SOME- $\dot{\vec{\circ}}$ ONE WHO IS SMARTER THAN YOU ARE. This is to your advantage as you will learn and grow immensely because of it.

If possible, ALWAYS HAVE AT LEAST THREE GOALS THAT MAY BE CONTINUOUSLY AND SIMULTANEOUSLY PURSUED: (1) Something you enjoy doing and that, if successful, might win you the Nobel prize. (2) Something $\stackrel{\leftrightarrow}{\omega}$ that may be a little risky but that will allow you to advance at a rate that is better $\stackrel{\sim}{x}$ than average. (3) Something that is sure to work; i.e., a bread-and-butter $\frac{\tilde{c}}{\sigma}$ project.

DO NOT KEEP RESEARCH SECRETS UNLESS YOUR EMPLOYER REQUITES IT. You will almost always gain more by sharing with others than by keeping secrets.

Administrators

MOST ADMINISTRATORS HAVE MORE PROBLEMS THAN YOU DO. ADMINISTRATORS ARE EMPLOYEES JUST LIKE YOU ARE.

BE LOYAL TO YOUR EMPLOYER AND ASSOCIATES. All people (including you) will tend to move to, and support, those they like. After all, do you invite o people you do not like to dinner? However, this does not mean you have to be subservient to your boss - just respect him/her and his/her problems and be helpful to your boss when you can.

ADMINISTRATORS NEED INFORMATION to help them see the overall picture of which you may be only a small part. Do what you can to help them put your work in perspective. Show how your work helps the organization that is supporting it.

YOU MUST LEARN, AND EFFECTIVELY APPLY, THE RULES THAT GOVERN YOUR ORGANIZATION if you are to advance.

\section{Miscellaneous}

BECOME FAMILIAR WITH THE CONCEPTS OF FAILURE. For example, some form of failure is almost always necessary for maximum productivity and personal advancement (e.g., Putt, 1978).

Similarly, UNDERSTAND WHEN YOU SHOULD AND SHOULD NOT BE COOP. ERATIVE WITH YOUR ASSOCIATES. Cooperation with an associate is usually, but not always, the best way to achieve one's goals. KNOW WHEN TO START AND WHEN TO STOP COOPERATING (e.g., Beardsley 1993, Brams 1993, Nowak and May 1992, Nowak and Sigmund 1993).

To be fundable, ALMOST ALL WORK NEEDS TO BE RELEVANT TO SOMETHING, preferably something that those who manage the funding agencies can understand and feel is important.

Conversely, ALMOST ANYTHING CAN BE MADE TO APPEAR RELEVANT IF YOU VIEW IT IN THE PROPER PERSPECTIVE.

WHO YOU KNOW, AND WHO YOU CAN EFFECTIVELY REACT WITH, ARE LIKELY TO BE MORE IMPORTANT THAN WHAT YOU KNOW.

\section{Publication}

\section{ALMOST ANYTHING IS PUBLISHABLE.}

AS SOON AS DATA INDICATE A TREND, START TO WRITE THE PAPER. This will tell you what you still need to do to finish the work. Even more important, it will let you know when the work is finished.

Better yet, WRITE THE PAPER BEFORE YOU START THE WORK. This may sound facetious, but it really does work and is probably the best way to increase productivity.

DON'T START A PROJECT UNLESS YOU HAVE A CLEAR GOAL. In the case of most academic research, this means a title for the paper that will result from the work.

IF SOMETHING DOES NOT SOUND GOOD AS WRITTEN, REWRITE IT BACKWARDS. This may be applied literally or figuratively depending on context. This is not a facetious idea, it really does work (W. Gordon Whaley, personnel communication). 
Doing research is easy. Getting data is easy. Writing a publishable paper can be easy - but usually is not. WRITING A PUBLISHABLE PAPER IS THE STEP WHERE MOST RESEARCHERS FAIL.

A RESEARCH PROJECT IS NOT COMPLETE UNTIL THE RESULTS ARE DISSEMINATED TO THOSE WHO MAY HAVE A USE FOR THEM.

MOST IDEAS HAVE TO BE REPEATED MANY TIMES IF THEY ARE TO BECOME A RECOGNIZED PART OF THE SCIENTIFIC LITERATURE.

CONVERSELY, A PERSON WHO SAYS SOMETHING ONLY ONCE SELDOM GETS CREDIT FOR THE IDEA.

IT IS OK TO CITE YOURSELF, the ultimate goal being to write a review paper in which only your publications are needed.

If your data do not support your original hypotheses, don't throw the data away. Practically all data are useful if you can be flexible enough to understand what they tell you. WHATEVER DATA YOU GET, USE IT TO YOUR ADVANTAGE.

THE MORE INNOVATIVE AND BRILLIANT AN IDEA, THE GREATER THE CHANCE THAT IT WILL BE REJECTED.

Conversely, A VERY POOR PAPER WILL BE REJECTED but, then, this is obvious.

\section{Personal}

PEOPLE ARE NOT CREATED EQUAL. It is important to accept this and learn to live with it.

GOOD PEOPLE WILL BE PRODUCTIVE IRRESPECTIVE OF THE EQUIPMENT OR ENVIRONMENT WITH WHICH THEY ARE ASSOCIATED. These people will make do with what is available, and prosper in spite of the difficulties. PEOPLE NEVER DO ANYTHING WITHOUT A REASON - although the real reason for doing something is often obscured or never expressed.

MOST ADVERSE HAPPENINGS THAT BEFALL YOU ARE SELDOM TOTALLY SOMEONE ELSE'S FAULT. It just may be possible that you had a part in bringing the happening to fruition.

ONE PERSON CAN OFTEN MAKE A DIFFERENCE if he/she really works at trying to do so. Almost all countries, businesses, charitable causes, and on down to the lowest units of organization, prosper or die because of one or two individuals. Just look at a bit of history to see that this is so.

The quality of an organization is recognized in part by the achievements of its personnel. Therefore, SOME DEGREE OF SELFISHNESS TOWARD ACHIEVING ONE'S PERSONAL RESEARCH GOALS MAY BE OF BENEFIT TO BOTH THE SCIENTIST AND THE ORGANIZATION WHICH HE/SHE REPRESENTS.

When the opportunity presents itself, YOU MUST GIVE THE IMPRESSION THAT YOU ARE WHAT IS NEEDED and, hopefully, this will be true.

NOT EVERYONE CAN HANDLE FREEDOM OF CHOICE IN DOING RESEARCH, nor should they be allowed to do so.

RECOGNIZE AND ACCEPT YOUR CAPABILITIES ANDS LIMITATIONS.

VERY FEW PEOPLE (even close friends) WILL HELP YOU IF, BY SO DOING, THEIR OWN WELFARE MAY BE ADVERSELY AFFECTED. This is essentially a restatement of Watson's third rule. Believe it.

\section{References}

Beardsley, T. (1993) Never give a sucker an even break. Sci. Am. 269:22.

Brams, S.J. (1993) Theory of moves. Am. Sci. 81:562-570

Nowak, M.S. May, R.M. (1992) Evolutionary games and spatial chaos. Nature 359:826-829.

Nowak, M.A., Sigmund, K. (1993) Chaos and the evolution of cooperation. Proc. Nat. Acad. Sci. U.S.A. 90:5091-5094

Putt, A. (1978) The successful technocrat. 3: The law of failure. Res.JDev. May, 1978 .

Watson, J.D. (1993) Succeeding in science: some rules of thumb. Science $261: 1812$.

\section{When Solutions Count... The Result $=\mu$ View Microscope Video Image Software!}

Spectra-Tech announces the introduction of $\mu$ View (Micro View), a powerful and versatile new Video Imaging Software for Visible and Infrared Microscopes. This Windows-compatible package greatly enhances sample viewing, image capture, annotation and documentation.

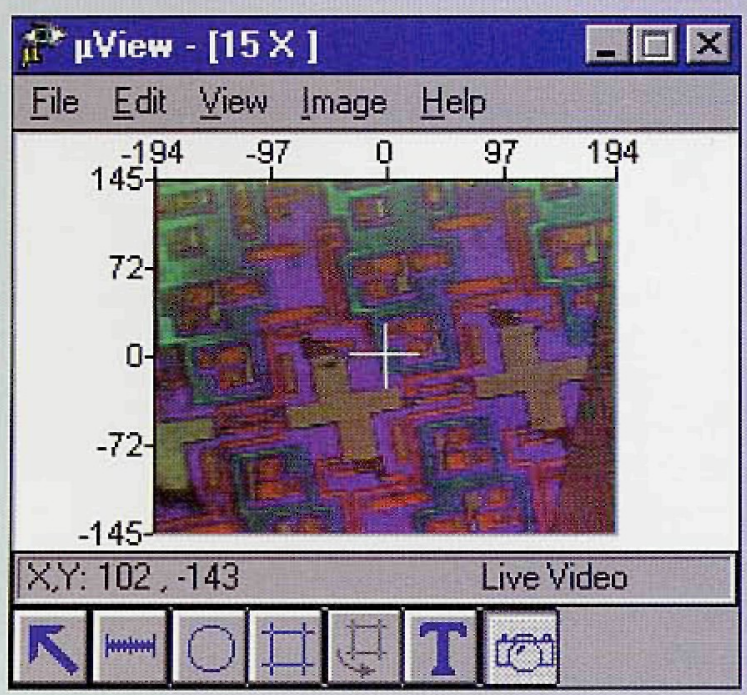

SPECTRATECHM

\section{Features:}

- Live sample image appears in a video pane in the Windows application

- Annotation, printing and saving measurements of sample dimensions

- Intuitive and easy to use

- Produces image files that contain true colors

- A scale surrounds the video image \& allows the viewer to determine the size of sample

- A cross hair displayed over the sample image indicates the center of the field of view

- Variety of useful tools

\section{$\mu$ View}

Spectra-Tech Inc., 2 Research Drive, Shelton, CT 06484-0869 Phone: 1-800-243-9186, CT 203-926-8998, Fax: 203-926-8909 